\title{
A LEARNER'S SELF-REGULATED LEARNING IN WRITING
}

\author{
Hapsari Dwi Kartika \\ Syarif Hidayatullah State Islamic University of Jakarta \\ (fasa.hdk2010@gmail.com)
}

Received: $04^{\text {th }}$ November 2015; Revised: $16^{\text {th }}$ December 2015; Accepted: $28^{\text {th }}$ December 2015

\section{ABSTRACT}

The purpose of this study was to analyze Self-Regulated Learning (SLR) upon the process of writing task. The Motivated and Learning Strategies Questionnaire (MLSQ) developed by Pintrich was used to generate the participant's cognitive and metacognitive activity. Data were collected from the participant's journal written during her task performance and from her scores from three essay assignments in Psychology and Instruction subject. The result indicated an improvement in the participant's writing performance, such as recalling previous knowledge and reviewing her writing. It showed that the participant's marks among the three assignments significantly increased. The result also indicated participant's difficulties and strength in her writing. However, The study further suggested time expansion to obtain a more comprehensive SLR performance, such as motivational and emotional aspects.

Key Words: self-regulated learning; writing task; graduate student

\section{ABSTRAK}

Penelitian ini bertujuan untuk menganalisa Self-Regulated Learning (SLR) terhadap proses dalam tugas menulis. Kuesioner motivasi dan strategi belajar (MLSQ) yang di kembangkan Pintrinch di gunakan untuk mengetahui aktifitas kognitif dan metacognitive partisipan. Data dikumpulkan dari tulisan jurnal partisipan selama mengerjakan tugas, serta data dari hasil tugas menulis essay dalam mata kuliah Psychology and Instruction. Hasil menunjukkan bahwa ada perkembangan dalam performa menulis partisipan, contohnya memanggil pengetahuan partisipan sebelumnya dan peninjauan kembali tulisannya. hasil tersebut menunjukkan bahwa nilai partisipan dari tiga tugas menulis mengalami peningkatan secara signifkan. Hasil studi juga memperlihatkan kesulitan dan kelebihan partisipan. Akan tetapi Studi ini menyarankan adanya perpanjangan waktu agar hasil performa SLR partisipan bisa lebih komprehensif, seperti pada aspek motivasi dan emosi partisipan.

Kata kunci: belajar dengan cara self-regulated; tugas menulis; pelajar pasca sarjana

How to Cite: Hapsari. (2015). A Learner's Self-Regulated Learning in Writing. IJEE (Indonesian Journal of English Education), 2(2), 120-131. doi:10.15408/ijee.v2i2.3085

Permalink/DOI: http://dx.doi.org/10.15408/ijee.v2i2.3085 


\section{INTRODUCTION}

In a university educational system, students are expected to be selfregulated in their learning (Winne \& Perry, 2000; Perry \& Vandekamp, 2000). They must start to be self-directed once entering the university. Also, They have to plan their own study such as selecting a particular topic that is suitable for their future career and discipline. They have to manage and monitor their study every time they have difficulty in learning and performing a task or taking examination. If a student fails to manage his or her own needs, he or she will be a poor-performer of academic achievement. Students must take responsibilities for their own learning (Zimmerman, 1990; Schapiro \& Livingston, 2000).

At this point, the researcher is taking herself as the participant in a case study. The participant has difficulty in writing and self-regulation. She makes particular mistakes in her writing and has a problem in managing her time when completing a task such as writing an essay. The participant assumed that her poor performance is not only due to her lack of knowledge about the content of a topic area, but also her self-regulation in performing essay writing.
Self-regulated learning (SRL) has been an interesting issue in many decades. Belief about how selfregulation is powerful to students' achievement has been examined (Muis \& Franco, 2009). There are also many studies that investigated the component of self-regulation adopted by students in their learning (Pintrich, Roeser, \& De Grrot, 1994; Malmivvouri, 2006; Harrison \& Prain, 2009). Motivation also has a strong relation with selfregulation that determine students goal in learning (Ames \& Archer, 1988). The number of research that related students' achievement in academic performance are greater than years before; they examined how self regulation can promote students' motivation in achieving higher academic level and well-performed in many domains, such as science and language (Eilama \& Aharon, 2003). High-achiever students demonstrate higher self-regulation in their learning (Zimmerman \& Pons, 1986; Eilama \& Aharon, 2003).

Furthermore, students in different cognitive development experience different self-regulation development. A study in a primary school found that students were self-regulated and collaborated with their teachers. In addition, teachers consistently involved young children to choose what their 
students would like to read and write in the classroom, and teachers also guide their students to evaluate their performance (Perry \& Vandekamp, 2000). ). Several studies have found the effectiveness of self-regulation program for school students. Support feedback from teachers and peers are helpful for students' self-regulation in secondary schools (Harrison \& Prain, 2009). Students in college and undergraduate students who demonstrate their selfregulation in learning indicates their skills advancement (Kitsantas \& Zimmerman, 2006). Pre-service teacher students also need to have a program and practice their self-regulation by self-questioning called IMPROVE (Kramarski \& Michalsky, 2010) to improve their skills.

In the context of higher education, self-regulation is crucial. Learning in a higher education demands higher thinking and analysis. Academic literacy such as reading and drawing expects students of a higher degree to adapt new learning styles to meet the standard of academic literacy. Adapting new ways to understand, interpret and organize their knowledge is related to higher learning (Lea \& Street, 1998). Research on self-regulation attempts to help students in higher education to have their best learning strategy by promoting students self-regulation in academic literacy.

With regards to self-regulation in writing, a profound model that helps a learner to be well-regulated in writing is designed by Flower and Hayes (1981). They divided the writing process into three steps. Planning, translating and reviewing is classified under one's cognitive monitoring (Flower \& Hayes, 1981). This model is reflected to self-regulation process in learning or performing a task; students are planning, monitoring and evaluating (Schraw, 1998). Three steps in writing, according to Flower and Hayes (1981) model, may be taught by employing self-regulation strategy to students. Extended and regular practice can augment students writing performance.

Self-regulation learning is applicable at any age and cognitive development. In other words, students in classroom context or higher education may be taught this strategy (Schunk \& Zimmerman, 1998). Students in lower level, such as in primary and secondary classroom need teacher or peer guide to employ self-regulation learning by explicit instruction in training (Zimmerman, Bonner \& Kovach, 1996). Hence, students in higher educatin may be more selfregulated to start practicing the strategy 
without control from academic staffs or teachers. Students in higher levels may not attend particular class that teaches them how to be self-regulated. They can find the strategy in a book or article that provides repertoire of self-regulation.

Considering the problems faced by the writer and the usefulness of SRL, the participant decided to design her plan in completing the last two essays as an intervention. She expected the intervention will bring about change to her study regulation and enable her to become aware of what she has to do when approaching a task

\section{METHOD}

The instruction is constructed and employed based on Flower and Hayes' (1981) steps on writing. The present project is aimed to enhance participant's self-regulated in her writing. The intervention will be selfreinforcement of the participant's task performance in writing. Based on the three process of writing, the participant was given a series of strategy in writing i.e. to plan, monitor and evaluate her assignment.

Prior to the instructional intervention, the participant undertook an SLR questionnaire designed and modified by the researcher from Motivated Strategies for Learning
Questioners or MLSQ (Pintrich, 1981). At the end of the intervention she was also given similar questionnaire to compare the two condition of the participant between the interventions.

\section{Participant}

The participant was a student of School of Education in Flinders University. In Australia, when someone conducts a research study, the researcher should consider the research ethic. This research study has adhered to that requirement. This project was a self-regulation learning description of the researcher. The participant was the researcher herself. This study was conducted as the researcher's final project as her fulfillment of Psychology and Instruction topic.

\section{Data collection}

There were three data collection employed. First, the data from a questionnaire was given to the participant at the beginning of the study and at the end of the study or after she wrote the last focus question assignment. There were 12 questions modified by the researcher. Some of the questions were adopted from MLSQ (Pintrich, 1981). The question was subjected to understand participant's self-regulated statement before and after the intervention. 
The second data collection was taken from the participant's journal written during her task performance from the first assigned essay of focus question to the third one. The data was to scrutinize participant's cognitive process and metacognitive activity. Therefore, the researcher used a protocol analysis, which has been successfully used to study other cognitive processes. It is also used as a medium of realizing self-regulation (Nuckles, Hubner \& Rankl, 2009).

The third data collection was based on the participant's scores from three essay assignments in Psychology and Instruction topic obtained from July 27 to November 4 . The essays were subjected to see the participant's comprehension between data collected and components of motivation, cognitive and metacognitive theory. The lecturer designed a standard in scoring the paper. This instrument was to look participant's academic performance.

The first and second data collections are appropriate methods to understand one's self-regulation. Selfreport questionnaire is frequently used as protocol in measuring self-regulated learning (Boekaerts, Pintrich, \&
Zeidner, 2000). The third method that looks at participant's achievement is the actual and representative performance from a whole class timeline.

\section{FINDING AND DISCUSSION}

\section{Findings}

The table 1 is participant's responds of her pre and post-test questionnaire modified from Pintrich (1981).

The respond is using yes or no statement. "Yes" means that the participant's did what a self-regulated learner does according to MLSQ. "No" means that the participant did not show the action in her writing process. The researcher modified some questions from MSLQ; she took some questions that she assumed represent a selfregulation learning and reflects the cognitive process in writing as Flower and Hayes (1981) had given. The ten questions are selected based on the researcher's initial perception about self regulation in writing. it indicates that the self-regulation occurred after the participant understand about her cognitive process. She get better in selfregulation after she interfered herself and practice it deliberately. 
IJEE (Indonesian Journal of English Education), 2 (2), 2015

Table 1. Participant's responds of her pre and post-test questionnaire

\begin{tabular}{clcc}
\hline No & \multicolumn{1}{c}{ Questionnaire } & $\begin{array}{c}\text { Pre- } \\
\text { test }\end{array}$ & $\begin{array}{c}\text { Post- } \\
\text { test }\end{array}$ \\
\hline 1 & I try to think through a topic and decide what I am supposed to do & No & Yes \\
2 & I usually write in a place where I can concentrate (Pintrich, 1981) & Yes & Yes \\
3 & I make a schedule on completing the task & No & Yes \\
4 & I find it easy to stick to the writing schedule (Pintrich, 1981) & No & Yes \\
5 & I search and read many references & No & Yes \\
6 & I check my grammar and spelling after and during writing. & Yes & Yes \\
7 & I have a friend of mine edited my work & No & Yes \\
9 & I usually find time to review my writing (Pintrich, 1981) & Yes & Yes \\
10 & I ask my lecture to clarify some point that I don't understand from the task & Yes & Yes \\
\hline
\end{tabular}

Table 2. Participant's cognitive process in writing as her self-regulation description in performing a task.

\begin{tabular}{lll}
\hline $\begin{array}{l}\text { Task / Essay } \\
\text { writing }\end{array}$ & $\begin{array}{l}\text { The cognitive } \\
\text { process. }\end{array}$ & $\begin{array}{l}\text { Indication of cognitive process based on } \\
\text { Flower and Hayes (1981). }\end{array}$ \\
\hline $\begin{array}{l}\text { Focus } \\
\text { question 2: } \\
\text { Learners are }\end{array}$ & $\begin{array}{l}\text { Planning: } \\
\text { Setting goal }\end{array}$ & $\begin{array}{l}\text { Wenerating } \\
\text { Writers form an internal representation of } \\
\text { the knowledge that will be used in writing }\end{array}$ \\
& $\begin{array}{l}\text { idea } \\
\text { Organizing }\end{array}$ & $\begin{array}{l}\text { Retrieving relevant information from long- } \\
\text { term memory. }\end{array}$
\end{tabular}

Writers identify first or last topics, important ideas, and presentation patterns

Establishing goal setting

Monitoring : Translating idea

\begin{abstract}
The process of translating requires the writer to juggle all the special demands of written English such as spelling and grammar, the task of translating can interfere with the more global process of planning what one wants to say.

Determines how long a writer will continue generating ideas before attempting to write prose
\end{abstract}

Quotes (Participant's journal)

No indication

"I summarize each article in a literature review form given by a lecture from another class. It is quite helpful to simplify my reading of an article."

"I start making a concept map of what I am going to write as an outline".

"I reread the article while striving constructing a paragraph."

"I write the paper in specific time. It takes some times because I have to find appropriate words."

\begin{tabular}{lll}
\hline Evaluation: & Writers choose to read what they have & "I read my paper and check the \\
Reviewing & written either as a springboard to further & spelling and grammar, and re- \\
& $\begin{array}{l}\text { translating or with an eye to systematically } \\
\text { evaluating and/or revising the text. }\end{array}$ & $\begin{array}{l}\text { arrange the organization of my } \\
\text { paper." }\end{array}$
\end{tabular}

An evaluation of either the text or one's own planning. 
IJEE (Indonesian Journal of English Education), 2 (2), 2015

\begin{tabular}{llll}
\hline $\begin{array}{c}\text { Task / Essay } \\
\text { writing }\end{array}$ & $\begin{array}{c}\text { The cognitive } \\
\text { process. }\end{array}$ & $\begin{array}{c}\text { Indication of cognitive process based on } \\
\text { Flower and Hayes (1981) }\end{array}$ & Quotes (Participant's journal) \\
\hline $\begin{array}{l}\text { Focus } \\
\text { question 3: }\end{array}$ & Planning & $\begin{array}{c}\text { Writers form an internal representation of } \\
\text { the knowledge that will be used in writing }\end{array}$ & $\begin{array}{l}\text { "This activity begins with typing } \\
\text { keywords in Flinders library } \\
\text { Learners are }\end{array}$ \\
Metacognitive & & $\begin{array}{l}\text { helpful books or article that } \\
\text { support my ideas" }\end{array}$ \\
& & $\begin{array}{l}\text { "I read several sources such as } \\
\text { articles or books, and take any }\end{array}$ \\
& & information about meta- \\
& & cognitive."
\end{tabular}

Retrieving relevant information from longterm memory.

Writers identify first or last topics, important ideas, and presentation patterns

Establishing goal setting.
"Before writing, I try to remember what knowledge I have about the metacognitive and cognitive from the classroom."

"Here is the schedule that I use during the day; this schedule is made to direct my writing process."

"how I say this" writer to juggle all the special demands of written English such as spelling and grammar, the task of translating can interfere with the more global process of planning what one wants to say.

Determines how long a writer will continue generating ideas before attempting to write prose

"I think I'll reread the last two that need appropriate vocabulary"

"is it better to use word in regard with or in conjunction with, or what word?"

"I start writing and translating my idea into a text. I write an introduction. My target is 100 or paragraphs. There are sentences 200 words for this section. But surely for 30 minutes writing, I make 100 words at least"

\begin{tabular}{ll}
\hline Evaluation & Writers choose to read what they have \\
written either as a springboard to further \\
translating or with an eye to systematically \\
evaluating and/or revising the text.
\end{tabular}

An evaluation of either the text or one's own planning.
"Proof read my writing, spelling and the flow of my thinking"

"Proofread my writing and check whether there something to add or miss out"

"had I completed the schedule?" 
Table above shows participant's writing process. There was no intervention at the first assignment because the participant perceived no self-regulation occurred in her writing process. However, in the second assignment, she started to interfere her work with self-regulated strategy. In the third assignment, the participant strictly monitored her intervention in the writing. However, according to Flower and Hayes (1981), planning, translating and reviewing remains under monitor of one's cognitive process.

In the first intervention in assignment 2, the participant did not find data showing her internal representation of a knowledge planning. Therefore, she took a key word as her first perception of her knowledge about the assignment in the second intervention.

However, a self-regulated learning is a brand new knowledge for the participant. She needs to reads more references to conducted rigorous study about self-regulation. She understands a small amount of self-regulation; subsequently, she derived the questionnaire from her own knowledge and some of the questions were similar to MSLQ.

Table 3. Marks from Focus Assignment Rubric

\begin{tabular}{|c|c|c|c|}
\hline$x^{2}+2$ & $\begin{array}{c}\text { Motivation } \\
\text { focus } \\
\text { question }\end{array}$ & $\begin{array}{c}\text { Cognitive } \\
\text { focus question }\end{array}$ & $\begin{array}{l}\text { Metacognition } \\
\text { focus question }\end{array}$ \\
\hline Data & & & \\
\hline Relevant data included & $\mathrm{P}$ & $P$ & C \\
\hline Data represented in appropriate formats & $\mathrm{P}$ & $\mathrm{C}$ & $\mathrm{C}$ \\
\hline Theory & & & \\
\hline Key area concept discussed & $\mathrm{C}$ & C & $\mathrm{C}$ \\
\hline Links between area concept elaborated & $\mathrm{P}$ & $\mathrm{P}$ & $\mathrm{p}$ \\
\hline Theory practice links & & & \\
\hline Links between area concept and data elaborated & $\mathrm{C}$ & C & $\mathrm{C}$ \\
\hline Big picture & & & \\
\hline $\begin{array}{l}\text { Evidence of development of an elaborated } \\
\text { mental model of an area }\end{array}$ & $\mathrm{P}$ & $\mathrm{P}$ & $\mathrm{P}$ \\
\hline Writing formalities & & & \\
\hline Organization/structure of proposition & $\mathrm{P}$ & $\mathrm{C}$ & $\mathrm{C}$ \\
\hline Overall score & $\mathrm{P}$ & $\mathrm{C}$ & $\mathrm{C}$ \\
\hline
\end{tabular}


Table 4. Grade Description

\begin{tabular}{|c|c|c|c|}
\hline & $F$ & $\mathrm{P}$ & C \\
\hline $\begin{array}{l}\text { Lecturer's } \\
\text { grade } \\
\text { description }\end{array}$ & $\begin{array}{l}\text { Unable to } \\
\text { demonstrate } \\
\text { satisfactory } \\
\text { academic } \\
\text { performance } \\
\text { in the topic or } \\
\text { has failed to } \\
\text { complete } \\
\text { essential topic } \\
\text { elements or } \\
\text { required } \\
\text { assessment } \\
\text { tasks at an } \\
\text { acceptable } \\
\text { level. In } \\
\text { accordance } \\
\text { with topic } \\
\text { objective }\end{array}$ & $\begin{array}{l}\text { Undertaken the required core } \\
\text { work for the topic and } \\
\text { demonstrated at least an } \\
\text { adequate level of } \\
\text { knowledge/understanding } \\
\text { competencies/ skill required } \\
\text { for meeting topic objectives } \\
\text { and satisfactory completing } \\
\text { essential assessment } \\
\text { exercises. } \\
\text { knowledge of matter } \\
\text { contained in set text or } \\
\text { reading material , and } \\
\text { demonstrated familiarity } \\
\text { with major academic debates, } \\
\text { approaches, methodologies } \\
\text { and conceptual tools. }\end{array}$ & $\begin{array}{l}\text { Undertaken all the required core } \\
\text { work for the topic the high level and } \\
\text { considerable additional work in } \\
\text { wider areas relevant to the topic has } \\
\text { demonstrated advance } \\
\text { knowledge/understanding } \\
\text { competencies/ skill required for } \\
\text { meeting topic objectives and } \\
\text { satisfactory completing essential } \\
\text { assessment exercises. Adequate } \\
\text { knowledge of matter contained in set } \\
\text { text or reading material, and } \\
\text { demonstrated familiarity with and } \\
\text { the ability to apply range of major } \\
\text { academic debates, approaches, } \\
\text { methodologies and conceptual tools. } \\
\text { Completed all course objectives and } \\
\text { shown considerable evidence of a } \\
\text { sound capacity to work with the } \\
\text { range of relevant subject matter. }\end{array}$ \\
\hline
\end{tabular}

The table above shows improvement in participant's writing performance. Those marks indicate that participant difficulties and strength in her writing. A self-regulated learning intervention has enhanced participant's problem in some area such as in the Data and Writing Formalities criteria.

$\mathrm{P}$ and $\mathrm{C}$ were marks given by the lecturer for the participant's overall writing score. Each score representes the participant's essay writing accomplishment such as its literature review, practical project justification, practical project design and step by step explanations, critical discussion, and formalities sentence structure and spelling. The university, where the participant studied, has its own assessment standard. Nevertheless, the lecturer also has a great deal to design his or her own essay writing assessment rubric.

\section{Discussion}

According to Flower and Hayes (as cited in Bruning et al., 2004), there are three processes in writing. The first is planning. At this stage, the writer generates and organizes her writing. For example, the writer activates her prior knowledge and discerns if she could relate a current task with her previous knowledge: 
“Before writing, I try to remember what knowledge I have about the metacognitive and cognitive from the classroom."

Recalling previous knowledge allows the participant' to activate her long-term memory. It is stated that "The second element is the writer's long-term memory in which the writer has stored knowledge, not only of the topic, but of the audience and of various writing plans" (Flower \& Hayes, 1981).

During this stages, the participant setting and designing her own schedule to manage her task (Winne \& Hadwin, 1998):

"Here is the schedule that I use during the day, this schedule is made to direct my writing process."

The next stage is initiated to translating her idea and perception into the text form according to the writer's knowledge transformation. This stage is fairly challenging as the participant struggles to write down her idea in the text form.

"How I say this" indicates the participant's confusion in articulating her idea in a word even in verbal. She tried to find appropriate diction and syntax that represent her idea.
A process of reviewing is not necessarily the end of a task. The reviewing process may lead another new planning or translating the idea into a text (Flower \& Hayes, 1981).

Self-regulation has a strong correlation with academic achievement. It showed that participant's mark among three assignments enhanced. The participant's planning and time management is developed in task essay writing focus question 3. It indicated that "High-achieving students generally exhibited more SRL skills (were better planners and managers of time) than did average achieving students." (Eilama \& Aharon, 2003)

There are many aspects or components of self-regulation that may be useful to be explored in the project. Task environment and motivation components may influence the participant's effort and dynamic in learning and performing a task (Schapiro \& Livingston, 2000). However, a further study is necessary to explore the participant's motivational and emotional aspects in her learning and performing a task. Furthermore, explicit instructional design-plansactivities should be interfered by the teacher or lecturer to acquire more appropriate result. 


\section{CONCLUSION AND SUGGESTION}

Higher education requires students to write an essay as a fulfillment of the requirements for their grade of academic achievement. Beside language, students may also have difficulty to regulate their own learning. In the present study, the participant has difficulty in writing and self-regulation. Some typical mistakes in her writing are reduced by improving the participant's SRL. In the intervention, the participants employed a profound model that helps a learner to well-regulated his or her writing. This was designed by Flower and Hayes (1981). They divided the writing process into three steps: planning, translating and reviewing. Analyses from three collected data showed meaningful improvement in the participant's writing.

The researcher suggests time extension to practice the SLR. She believes the more the participant demonstrates self regulated, the better she performs. The questionnaires employed should represent multidimensional aspects which more likely indicate participant's motivation, cognitive and metacognitive statement. If the SLR is aimed to be taught in the classroom, it should be presented directly and explicitly by the teacher.

\section{REFERENCES}

Ames, C. \& Archer, J. (1988). Achievement goals in the classroom: Students' learning strategies and motivation processes. Journal of Educational Psychology, 80(3), 260-267.

Boekaerts, M., Pintrich, P. R., \& Zeidner, M. (Eds.). (2000). Handbook of self-regulation. California: Academic Press.

Eilama, B. \& Aharon, I. (2003). Students' planning in the process of Selfregulated learning. Contemporary Educational Psychology, 28, 304334.

Flower, L. \& Hayes, J. R. (1981). A cognitive process theory of writing source: College composition and communication. Remedial and Special Education, 32(4), 365-387.

Graham, S., Harris, K. R., \& Mason, L (2005). Improving the writing performance, knowledge, and self-efficacy of struggling young writers: The effects of selfregulated Strategy development. Contemporary Educational Psychology, 30, 207-241.

Harrison, S. \& Prain, V (2009). Selfregulated learning in junior 
secondary English. Issues in Educational Research, 19(3).

Kitsantas, A. \& Zimmerman, B. J. (2006). How can primary school students learn self-regulated learning Strategies most effectively? Enhancing selfregulation of practice: The influence of graphing and selfevaluative standards. Metacognition Learning, 1, 201-212, doi: 10.1007/s11409-006-9000-7

Kramarski, B. \& Michalsky, T. (2010). Preparing preservice teachers for self-regulated learning In the context of technological pedagogical content knowledge. Learning and Instruction, 20, 434447.

Lea, M. R. \& Street, B. V. (1998). Students writing in higher education: An academic literacy approach. Studies in Higher Education, 2, p. 157.

Muis, K., R. \& Franco, G., M. (2009). Epistemic beliefs: Setting the standards for self-regulated learning. Contemporary Educational Psychology, 34, 306-318.

Nu"ckles, Matthias., Hu“bner, S., \& Renkl, A. (2009). Enhancing selfregulated learning by writing learning protocols. Learning and Instruction, 19, 259-271.
Perry, N. E. \& Vandekamp, K. J. O. (2000). Creating classroom contexts that support young Children's development of selfregulated learning. International Journal of Educational Research, 33, 821-843.

Pintrich, P. R., Roeser, R. W., \& De Groot, E. A. M. (1994). Classroom and individual differences in early adolescents' motivation and self-regulated learning. The Journal of Early Adolescence, 14, 139.

Schapiro, S. R. \& Livingston, J. A. (2000). Dynamic self-regulation: The driving Force behind academic achievement. Innovative Higher Education, 25(1).

Winne, P. J. (1996). A metacognitive view of Individual differences in Self-regulated learning. Learning and Individual Differences, 8(4), 327-353.

Zimmerman, B. J. \& Pons, M. M. (1986). Development of a structured interview for Assessing student use of self-regulated Learning strategies. American Educational Research Journal, 23(4), 614-628. 